\title{
Biochemical changes in diabetic rats treated with ethanolic extract of Chysophyllum albidum fruit-skin
}

\author{
Samuel Ogheneovo Asagba ${ }^{1 *}$, Helen Ejiro Kadiri ${ }^{1}$ and Theresa Ezedom²
}

\begin{abstract}
Background: Diabetes mellitus (DM), also known as diabetes, involves a group of metabolic disorders in which blood sugar levels are high over a prolonged period. The present study was designed to evaluate the effect of 21 days administration of 100 and 200 mg per kg bodyweight of ethanolic extract of Chrysophyllum albidum (African star apple) fruit-skin on streptozotocin (STZ)-diabetic Wistar albino rats. A randomized control trial was used. Diabetic state of test rats was induced with streptozotocin at a dose of $60 \mathrm{mg}$ streptozotocin/ $\mathrm{kg}$ body using saline $(0.9 \% \mathrm{~W} / \mathrm{V} \mathrm{NaCl})$ as vehicle. Upon confirmation of diabetic state, crude ethanolic extract of $C$. albidum was dissolved in citrate buffer at $\mathrm{pH} 4.2$ before administration to the rats at specific doses.

Results: Results show a significant $(p<0.05)$ decreased in the level of plasma creatinine and insulin but increased level of glucose in diabetic rats relative to control. Induction of diabetes significantly increased the activities of alanine aminotransferases and aspartate aminotransferases in the liver and kidney and activities of both enzymes were also correspondingly increased in the plasma. There was significant increase in the level of total cholesterol, low-density lipoprotein-cholesterol, very low-density lipoprotein-cholesterol and triglyceride, but decreased highdensity lipoprotein-cholesterol in the test rats. Results also show alterations in the antioxidant status of experimental rats. The diabetic-induced changes were reversed in diabetic rats upon administration of $C$. albidum extract at a dose of $200 \mathrm{mg} / \mathrm{kg}$ body weight to levels comparable with control.

Conclusion: The findings obtained revealed that ethanolic extract of C. albidum fruit-skin at a dose of $200 \mathrm{mg} / \mathrm{kg}$ body weight reversed the effect of diabetes due to its antihyperglycemic, anti-hyperlipidemic and antioxidant properties. The antidiabetic effect of the extract may be due to its abundant flavonoid and alkaloid contents.
\end{abstract}

Keywords: Streptozotocin, Therapeutic agent, Oxidative stress, Lipid profile, Indigenous metabolite

\section{Background}

Diabetes mellitus (DM) is a multifactorial disease which is characterized by hyperglycaemia, lipoprotein abnormalities and altered intermediary metabolism (Mediani et al., 2018). DM is a common disease and also a prevalent one affecting the citizens of both developed and developing countries. According to Karalliedde and Gnudi (2016), DM is a heterogeneous condition which occurs when there is defect in insulin production by the pancreas, insulin resistance/action or a combination of

\footnotetext{
* Correspondence: asagbabch@yahoo.com; soasagba@delsu.edu.ng 'Department of Biochemistry, Delta State University, P.M.B 1, Abraka, Nigeria Full list of author information is available at the end of the article
}

both, which leads to an increased concentration of glucose in the blood (hyperglycaemia).

Oxidative stress is caused by increased free-radical production or reduced activity of antioxidant defences or both and has been implicated as one the major causes of DM (Liguori et al., 2018). During diabetes, persistent hyperglycaemia causes increased free radical production in the tissues from glucose autooxidation, protein glycosylation, impaired glutathione metabolism, alteration in antioxidant enzymes, lipid peroxides formation, increased serum aminotransferases (ALT and AST) and decreased ascorbic acid levels (Asmat, Abad, \& Ismail, 2016; Lapena, Ciofani, Calafiore, Cipollone, \& Porreca, 2018; Sheweita, Mashaly, Newairy, Abdou, \& Eweda, 2016). Diabetes also produces disturbances of lipid 
metabolism, especially an increased susceptibility to lipid peroxidation, which is responsible for increased incidence of atherosclerosis, a major cause of mortality among people with type 2 diabetes mellitus (T2DM) (Alloubani, Saleh, \& Abdelhafiz, 2018; Einarson, Acs, Ludwig, \& Panton, 2018; Sarfo, Mobula, Plange-Rhule, Ansong, \& Ofori-Adjei, 2018; Yandrapalli, Jolly, Horblitt, Sanaani, \& Aronow, 2017).

The pathogenesis of DM and the possibility of its management by existing therapeutic agents without any side effects have stimulated great interest in recent years (Marshall, 2017). Management of DM without any side effects is still a challenge for the medical system which has led to an increasing search for improved antidiabetic drugs. Studies have shown that plants are useful to man, not only as food or a source of raw materials for various industries but also as source of medicine. African star apple fruit (Chrysophylum albidum) also known as cherry is primarily a forest tree species that belongs to the family Sapotaceace and its natural occurrences have been reported in diverse ecological zones in Nigeria, Niger Republic, Uganda, Cameroon and Cote d'Ivore (Bada, 1997). It often grows to a height of $36.5 \mathrm{~m}$ though it may be smaller due to climatic factor. Its fruit is a large berry containing 4-5 flattened seeds or sometimes fewer due to seed abortion (Keay, 1989). Cherry plant has in recent years become a commercial crop in Nigeria. The fleshy pulp of the fruits is eaten especially as snack and relished by both young and old (Bada, 1997; Keay, 1989). Cherries contain anthocyanins, the red pigment in berries which have been shown to possess anti-cancer and anti-inflammatory properties. Cherries are high in vitamin $C$ (ascorbic acid), carbohydrates and water and also contain trace amount of fibre, protein, vitamin $\mathrm{A}$, niacin, calcium, phosphorus, iron, magnesium, manganese, copper and potassium (Adepoju \& Adeniji, 2012). As a medicinal plant, cherry is commonly used as antimicrobial, anti-inflammatory and antioxidant agent by traditional medicine practitioners in Nigeria (Idowu, Iwalewa, Aderogba, Akinpelu, \& Ogundaini, 2006).

Despite the many medicinal uses of cherry, only few studies are available on the antioxidant and antihyperglycemic effect of the plant's components. Studies on the biochemical effects of extracts of other edible parts of the fruit such as the fruit-skin are scarce in literature. Therefore, the present study was undertaken to study the effect of ethanolic extract of Chrysophyllum albidum (C. albidum) fruit-skin on liver and kidney function parameters, oxidative stress parameters, tissue lipid profile as well as levels of plasma insulin and glucose in streptotozin (STZ) administered rats.

\section{Materials and methods}

\section{Plant material}

C. albidum fruits were bought from a local market in Abraka, Nigeria. The fruit-skin were removed from the outer covering of the fruits, air dried and grounded into powder.

\section{Preparation of ethanolic extract of plant fruit-skin}

Six hundred (600) grams of powdered C. albidum plant fruit-skin were first soaked for $30 \mathrm{~min}$ in $300 \mathrm{ml}$ of hexane to de-fat. The extract was filtered and the residue was soaked in $900 \mathrm{ml}$ of $70 \%$ ethanol for 5 days. The extract was filtered again and concentrated at $78{ }^{\circ} \mathrm{C}$ using rotary evaporator and further concentrated using water bath at $48^{\circ} \mathrm{C}$.

\section{Experimental animals}

Forty-two (42) male albino Wister rats (Rattus norvegicus domesticus) weighing between 120 and $140 \mathrm{~g}$ were used for the study. The animals were bought from the animal house of the College of Basic medical sciences, Delta State University, Abraka, Nigeria. The animals were housed in standard cages and allowed to acclimatize for 2 weeks to laboratory conditions. During this period, they were fed ad-libitum with rat chow obtained from Livestock Feeds Nigeria Limited (Lagos, Nigeria).

\section{Induction of diabetes mellitus}

After the period of acclimatization, test rats were given a single intraperitonial injection of freshly prepared streptozotocin using saline $(0.9 \% \mathrm{w} / \mathrm{v} \mathrm{NaCl})$ as vehicle, at a dose of $60 \mathrm{mg}$ streptozotocin $/ \mathrm{kg}$ body weight as previously described by Wu and Huan (2008). The diabetic state was ascertained in terms of loss of body weight and high blood glucose levels. Symptoms of diabetes were observed within 1 week of streptozotocin injection.

\section{Experimental design}

The 42 rats were divided into six groups with seven rats each. The crude extract was dissolved in citrate buffer at $\mathrm{pH} 4.2$ before administration to the rats. All administrations were done orally using gastric intubator and were done once daily for a period of 21 days as shown in Table 1. The doses of the extract employed during administration were below the $\mathrm{LD}_{50}$ value $(>5000 \mathrm{mg} / \mathrm{kg}$ bodyweight) predetermined from preliminary investigation.

After 21 days, the rats were allowed to fast for $24 \mathrm{~h}$ before been sacrificed under chloroform anaesthesia. Blood collected directly from the left ventricle of the heart and transferred to heparin tubes were centrifuged at $3000 \mathrm{~g}$ for $10 \mathrm{~min}$ to obtain plasma for biochemical analysis. The liver and kidney were also excised from the rats. Ten percent homogenates were prepared from each tissue using cold saline. The homogenates were centrifuged at $5000 \mathrm{~g}$ under cold conditions and the supernatants obtained were also used for biochemical analysis. All animal treatments were done in accordance with the guidelines for laboratory animal care as stipulated by NIH publication no 85-93, revised 1985. 
Table 1 Experimental design

\begin{tabular}{lll}
\hline Group & Number of rats & Treatment \\
\hline Group A. Normal control (NC) & 7 & Distilled water in place of extract \\
Group B. Diabetic control (DC) & 7 & Distilled water in place of extract \\
Group C. Non-diabetic (ND-200 & 7 & Extract (200 mg/kg body weight). \\
Group D. Non-diabetic (ND-100) & 7 & Extract (100 mg/kg body weight \\
Group E. Diabetic (D-200) & 7 & Extract (200 mg/kg body weight) \\
Group F. Diabetic (D-100) & 7 & Extract (100 mg/kg body weight)
\end{tabular}

NC normal control rats: animals received distilled water in place of extract, $D C$ diabetic control rats: animals received distilled water in place of extract, ND-200 non-diabetic rats: animals received $200 \mathrm{mg} / \mathrm{kg}$ body weight of extract, $N D-100$ non-diabetic rats: animals received $100 \mathrm{mg} / \mathrm{kg}$ body weight of extract, $D$ - 200 diabetic rats: animals received $200 \mathrm{mg} / \mathrm{kg}$ of extract, $D-100$ diabetic rats: animals received $100 \mathrm{mg} / \mathrm{kg}$ of extract

\section{Phytochemical analysis}

The qualitative and phytochemical analysis of C. albidum fruit-skin extract was evaluated by the methods of Harborne (1998) and Muhammad and Abubakar (2016).

\section{Biochemical analysis}

Glucose levels in the plasma were measured using the glucose oxidase method as stated in the leaflet of Randox laboratory kits. Plasma insulin concentrations were measured using a rat-specific radioimmunoassay kit procedure of Linco, Inc. (St Louis. MO). The L-alanine aminotransferases (L-ALT) and L-aspartate aminotransferase (L-AST) activities in plasma and tissues were determined by the method of Reitman and Frankel (1957). The activities of the enzymes were extrapolated from a standard curve and expressed as units/ml. Total cholesterol (total-C) and triglycerides (TRG) of serum were estimated by using standard methods (Zlatkis, Zak, \& Boyle, 1953) Serum high-density cholesterol (HDL-C) was determined by phosphotungstate/magnesium method (Lyons, 1992). Serum very low-density lipoproteincholesterol (VLDL-C) was calculated as triglyceride/5 and serum low-density lipoprotein-cholesterol (LDL-C) was calculated by the equation: LDL-C $=$ total $-\mathrm{C}-(\mathrm{HDL}-\mathrm{C}+$ VLDL-C). The glutathione (GSH) concentration in the samples was measured by the method of Tietz (1969) based on the reduction of 5,5 dithiobis (2-nitrobenzoic acid) (DTNB) with GSH to produce a yellow compound. The activity of glutathione-s-transferase (GST) was measured using the method of Habig, Pabst, and Jakoby (1974) based on the measurement of 1-chloro-2,4, dinitrobenzene (CDNB) with GSH that produces a dinitrophenyl thioether which can be detected at $340 \mathrm{~nm}$. The activity of the enzyme is expressed in mmole of CDNB-GSH conjugate/min/mg protein. Glutathione reductase (GR) activity was determined by the method of Carlberg and Mannervik (1985) and expressed as 4moles of GSH utilized/min/ $\mathrm{mg}$ protein. Glutathione peroxidase (GPx) activity was measured using the method of Flohé and Günzler (1984) and expressed as $\mu \mathrm{g}$ of GSH consumed $/ \mathrm{min} / \mathrm{mg}$ protein. The methods of Baum and Scandalios (1981) and Misra and Fridovich (1972) were used for the estimation and computation of the activity of superoxide dismutase (SOD), respectively. One unit of the enzyme activity represents the amount of the enzyme required for $50 \%$ inhibition of epinephrine during $1 \mathrm{~min}$. The level of lipid peroxidation (LPO) was determined by the method of Hunter, Gebicki, Hoffstein, Weinstein, and Scott (1963) as modified by Gutteridge and Wilkins (1982) using thiobarbituric acid reactive substance (TBARS) which are indicators of LPO. Values for TBARS are estimated with a molar extinction coefficient of $1.56 \times 10^{5} \mathrm{M} / \mathrm{cm}$ and expressed as nanomoles malondialdyde (MDA) per gram protein. The protein content of the samples was estimated by the method of Lowry, Rosebrough, Farr, and Randall (1951).

\section{Statistical analysis}

The results are presented as mean \pm SEM. The mean values of the groups were compared using analysis of variance (ANOVA) and the significance level was at $p<0.05$.

\section{Results}

\section{Qualitative and quantitative phytochemical screening of C. albidum}

The results of the qualitative and quantitative phytochemical screening of C. albidum fruit-skin is presented in Table 2. The qualitative screening revealed the presence of trace amounts of saponin and moderately concentrated amounts of tannins. There was also highly concentrated amount of alkaloids and flavonoids. The quantitative phytochemical analysis of $C$. albidum fruit skin shows that the values for the phytochemicals were in the order: flavonoids $>$ alkaloids $>$ tannins $>$ saponins.

\section{Evaluation of body weight gain and organ/bodyweight ratio of diabetic rats}

The effect of $C$. albidum fruit-skin extract on body weight gain and organ/body weight ratio for kidney and liver of rats is presented in Table 3. A negative body weight gain was observed in diabetic control rats relative to normal control rats. However, no significant change was observed in the body weight gain of non-diabetic 
Table 2 The qualitative and quantitative phytochemical values of C. albidum fruit skin

\begin{tabular}{lll}
\hline Phytochemicals & Qualitative & Quantitative $(\mathrm{mg} / 100 \mathrm{~g})$ \\
\hline Tannins & ++ & $120.60 \pm 2.40$ \\
Saponins & + & $0.034 \pm 0.0024$ \\
Flavonoids & +++ & $420.78 \pm 1.50$ \\
Alkaloids & +++ & $250.60 \pm 3.70$ \\
\hline
\end{tabular}

(+) Presence of trace amounts, ++ presence of moderate amounts, +++ presence of highly concentrated amounts

rats treated with 100 and $200 \mathrm{mg}$ of extract per kilogram body weight in relation to control rats. The diabetes induced body weight loss was reduced in a dosedependent manner after treatment with the extract.

The organ/body weight ratio for the liver and kidney of diabetic control rats was significantly increased relative to control. In contrast, no significant change was observed in this parameter for liver and kidney of nondiabetic rats administered both doses of the extract as compared to control rats. Similarly, no significant change was observed in the organ/bodyweight ratio for the liver and kidney of diabetic rats treated with $100 \mathrm{mg}$ (liver excluded) and $200 \mathrm{mg}$ of extract $/ \mathrm{kg}$ body weight. The liver/body weight ratio of diabetic rats remained significantly increased after treatment with $100 \mathrm{mg}$ extract/kg body weight.

Therefore, the study reveals that the extract reversed the negative effect of diabetes on weight gain of rats, although this parameter did not return to normal level as the observed weight loss remained evident. The extract (especially the higher dose) also reversed the effect of diabetes on the relative weight of the liver and kidney.

\section{Evaluation of plasma biochemical parameters}

Table 4 represents the effect of ethanolic extract of $C$. albidum fruit-skin on levels of plasma glucose, insulin, creatinine and aminotransferases of diabetic rats. The plasma glucose level of diabetic control rats was significantly increased relative to normal control. Conversely, normal rats treated with $200 \mathrm{mg}$ extract/ $\mathrm{kg}$ body weight had a significantly decreased plasma glucose concentration, but no significant difference was observed in this parameter in rats treated with $100 \mathrm{mg}$ extract/ $\mathrm{kg}$ bodyweight relative to normal control rats. The plasma glucose concentration of diabetic rats treated with both doses of the extract was significantly increased relative to normal control rats. However, in relation to diabetic control rats, the plasma glucose concentration of diabetic rats treated with $200 \mathrm{mg}$ extract $/ \mathrm{kg}$ bodyweight was significantly decreased.

Insulin levels in diabetic control rats were significantly reduced compared to those of normal controls. However, control rats treated alone with both doses of the extract did not show any significant change in level of plasma insulin when compared to those of control group. No significant change was observed in the level of plasma insulin between rats administered the higher and lower dose of extract of C. albidum fruit-skin, but this parameter was significantly increased when compared to diabetic control rats.

The level of plasma ALT, AST, and creatinine of diabetic control rats were significantly $(p<0.05)$ increased than normal control rats. Conversely, no significant difference was observed in these parameters in nondiabetic rats treated with both doses of the extract in relation to normal control. On the other hand, treatment of diabetic rats with both doses of the extract significantly increased the level of this parameter with respect to diabetic control rats. Thus the study indicates that $C$. albidum reversed the effect of diabetes on level of plasma ALT, AST, glucose, insulin and creatinine but the effect of the extract was dose dependent.

\section{Assessment of tissue aminotransferases activities}

The effect of extract of $C$. albidum fruit-skin on liver and kidney aminotransferases activities of diabetic rats is presented in Table 5. Like in the plasma, the activity of the liver aminotransferases (ALT and AST) was significantly increased in diabetic control rats in relation to normal control. Also, as previously observed in plasma,

Table 3 Effect of C. albidum extract on body weight gain and organ/body weight ratio for kidney and liver of diabetic rats

\begin{tabular}{llll}
\hline Treatments/group & \multicolumn{2}{l}{ Parameter } & \\
\cline { 2 - 4 } & Liver/body weight & Kidney/body weight & $41.28 \pm 5.22^{\mathrm{a}}$ \\
\hline Group A (NC) & $35.00 \pm 3.16^{\mathrm{a}}$ & $2.70 \pm 0.7^{\mathrm{a}}$ & $-17.28 \pm 4.40^{\mathrm{b}}$ \\
Group B (DC) & $49.50 \pm 1.73^{\mathrm{b}}$ & $3.60 \pm 0.2^{\mathrm{b}}$ & $43.55 \pm 9.61^{\mathrm{a}}$ \\
Group C (ND-200) & $35.75 \pm 3.6^{\mathrm{a}}$ & $2.73 \pm 0.60^{\mathrm{a}}$ & $38.85 \pm 4.52^{\mathrm{a}}$ \\
Group D (ND-100) & $36.70 \pm 4.20^{\mathrm{a}}$ & $2.68 \pm 0.5^{\mathrm{a}}$ & $-4.40 \pm 0.10^{\mathrm{c}}$ \\
Group E (D-200) & $32.30 \pm 7.63^{\mathrm{a}}$ & $2.62 \pm 0.6^{\mathrm{a}}$ & $-12.30 \pm 5.6^{\mathrm{d}}$ \\
Group F (D-100) & $42.58 \pm 8.26^{\mathrm{c}}$ & $2.74 \pm 0.7^{\mathrm{a}}$ &
\end{tabular}

The results are presented as mean \pm SEM. Value not sharing a common superscript on the same column differ significantly $(p<0.05)$ from each other NC normal control rats: animals received distilled water in place of extract, DC diabetic control rats: animals received distilled water in place of extract, ND-200 non-diabetic rats: animals received $200 \mathrm{mg} / \mathrm{kg}$ body weight of extract, $N D-100$ non-diabetic rats: animals received $100 \mathrm{mg} / \mathrm{kg}$ body weight of extract, $D$-200 diabetic rats: animals received $200 \mathrm{mg} / \mathrm{kg}$ of extract, $D-100$ diabetic rats: animals received $100 \mathrm{mg} / \mathrm{kg}$ of extract 
Table 4 Effect of C. albidum extract on levels of plasma glucose, insulin, creatinine and aminotransferases of diabetic rats

\begin{tabular}{llllll}
\hline Treatment/group & Parameter & & & \\
\cline { 2 - 6 } & Glucose & Insulin & Creatinine & ALT & AST \\
\hline Group A (NC) & $185 \pm 18.30^{\mathrm{a}}$ & $14.30 \pm 0.50^{\mathrm{a}}$ & $13.09 \pm 0.84^{\mathrm{a}}$ & $86.50 \pm 6.70^{\mathrm{a}}$ & $170.28 \pm 25.22^{\mathrm{a}}$ \\
Group B (DC) & $280.50 \pm 20.56^{\mathrm{b}}$ & $6.40 \pm 0.42^{\mathrm{b}}$ & $28.84 \pm 0.12^{\mathrm{b}}$ & $158.00 \pm 10.20^{\mathrm{b}}$ & $350.28 \pm 34.40^{\mathrm{b}}$ \\
Group C (ND-200) & $155.70 \pm 15.60^{\mathrm{c}}$ & $13.24 \pm 0.54^{\mathrm{a}}$ & $12.37 \pm 0.35^{\mathrm{a}}$ & $88.70 \pm 10.30^{\mathrm{a}}$ & $185.55 \pm 50.61^{\mathrm{a}}$ \\
Group D (ND-100) & $169.35 \pm 14.20^{\mathrm{a}}$ & $13.20 \pm 0.40^{\mathrm{a}}$ & $11.99 \pm 0.12^{\mathrm{a}}$ & $80.85 \pm 18.60^{\mathrm{a}}$ & $165.85 \pm 14.52^{\mathrm{a}}$ \\
Group E (D-200) & $230.30 \pm 21.63^{\mathrm{d}}$ & $10.80 \pm 0.60^{\mathrm{c}}$ & $15.95 \pm 0.23^{\mathrm{c}}$ & $105.75 \pm 8.50^{\mathrm{c}}$ & $195.40 \pm 42.10^{\mathrm{c}}$ \\
Group F (D-100) & $255.58 \pm 22.26^{\mathrm{e}}$ & $10.45 \pm 0.50^{\mathrm{c}}$ & $20.06 \pm 2.29^{\mathrm{d}}$ & $130.60 \pm 10.20^{\mathrm{d}}$ & $230.30 \pm 15.6^{\mathrm{d}}$ \\
\hline
\end{tabular}

The results are presented as mean \pm SEM. Value not sharing a common superscript on the same column differ significantly $(p<0.05)$ from each other

Values for plasma glucose and creatinine are given as $\mathrm{mg} / \mathrm{Dl}$, while aminotransferases and insulin are in units $/ \mathrm{ml}$ and $\mathrm{ng} / \mathrm{ml}$ respectively. $\mathrm{NC}$ normal control rats: animals received distilled water in place of extract, DC diabetic control rats: animals received distilled water in place of extract, ND-200 non-diabetic rats: animals received $200 \mathrm{mg} / \mathrm{kg}$ body weight of extract, ND-100 non-diabetic rats: animals received $100 \mathrm{mg} / \mathrm{kg}$ body weight of extract, $D-200$ diabetic rats: animals received $200 \mathrm{mg} / \mathrm{kg}$ of extract, $D-100$ diabetic rats: animals received $100 \mathrm{mg} / \mathrm{kg}$ of extract

no significant difference occurred in liver of non-diabetic rats administered both doses of the extract relative to normal control rats. The effect of diabetes on the activity of both enzymes was also reversed in liver of diabetic rats administered both doses of the extract. However, the effect of the extract on the diabetes-induced increase in activity of the aminotransferases was dose dependent. No significant change was observed in kidney ALT and AST of rats in all experimental groups. Hence, like in the plasma, this study shows that the effect of diabetes on liver ALT and AST was reversed by C. albidum but the effect depends on the dose administered.

\section{Evaluation of plasma lipid profile}

Table 6 presents the effect of ethanolic extract of $C$. albidum fruit-skin on plasma lipid profile of diabetic rats. The plasma total-C, TRG and LDL-C of diabetic rats were significantly increased relative to control. However, these parameters were significantly decreased (VLDL-C excluded) in normal rats treated with both doses of the extract relative control rats. There was no significant difference in plasma VLDL-C concentration in normal rats treated with $200 \mathrm{mg}$ extract $/ \mathrm{kg}$ body weight, but this parameter was significantly increased in normal rats treated with the lower dose. The effect of diabetes on these parameters was reversed in rats treated with the extract as the values of these parameters were significantly lower than diabetic control rats. The effect of the extract on plasma total-C, TRG and LDL-C in both normal and diabetic rats increased with increased dose. On the other hand, the plasma HDL-C concentration was significantly decreased in diabetic rats relative to control. However, treatment of normal rats with both doses of the extract significantly increased this parameter relative to normal control. The effect of diabetes on plasma HDL-C was reversed in diabetic rats treated with both doses of the extracts as the values were maintained at levels not significantly different from control rats. Thus, the study indicates that diabetes altered lipid profile while $C$. albidum reversed the effect of diabetes on lipid profile.

\section{Assessment of liver antioxidant status}

The level of LPO, SOD, GSH, GR, GST and GPx in the liver of rats in the various experimental groups is presented in Table 7 . The level of LPO was significantly

Table 5 Effect of C. albidum extract on tissue ALT and AST activities of diabetic rats

\begin{tabular}{|c|c|c|c|c|}
\hline \multirow[t]{3}{*}{ Treatment/group } & \multicolumn{4}{|l|}{ Parameter } \\
\hline & \multicolumn{2}{|l|}{$\mathrm{ALT}$} & \multicolumn{2}{|l|}{ AST } \\
\hline & Liver & Kidney & Liver & Kidney \\
\hline Group A (NC) & $1580.00 \pm 153.10^{a}$ & $402.70 \pm 20.70^{a}$ & $3041.28 \pm 105.22^{a}$ & $800.70 \pm 40.70^{a}$ \\
\hline Group B (DC) & $2500.50 \pm 115.73^{b}$ & $395.00 \pm 30.25^{a}$ & $5850.28 \pm 154.40^{b}$ & $700.50 \pm 126.82^{a}$ \\
\hline Group C (ND-200) & $1530.75 \pm 320.60^{a}$ & $380.85 \pm 30.60^{a}$ & $3053.55 \pm 190.61^{a}$ & $648.80 \pm 150.70^{a}$ \\
\hline Group D (ND-100) & $1590.70 \pm 104.20^{a}$ & $420.70 \pm 20.50^{a}$ & $3020.85 \pm 145.52^{a}$ & $680 \pm 130.00^{a}$ \\
\hline Group E (D-200) & $1540.30 \pm 357.63^{a}$ & $412.65 \pm 330.65^{a}$ & $3250.00 \pm 270.10^{a}$ & $880 \pm 105.00^{e}$ \\
\hline Group F (D-100) & $1820.58 \pm 280.26^{c}$ & $430.75 \pm 40.70^{a}$ & $3870.30 \pm 150.6^{c}$ & $920 \pm 180.60^{a}$ \\
\hline
\end{tabular}

The results are presented as mean \pm SEM. Value not sharing a common superscript on the same column differ significantly $(p<0.05)$ from each other The activity of aminotransferases is expressed in units $/ \mathrm{ml}$. NC normal control rats: animals received distilled water in place of extract, $D C$ diabetic control rats: animals received distilled water in place of extract, ND-200 non-diabetic rats: animals received $200 \mathrm{mg} / \mathrm{kg}$ body weight of extract, ND-100 non-diabetic rats: animals received $100 \mathrm{mg} / \mathrm{kg}$ body weight of extract, $D-200$ diabetic rats: animals received $200 \mathrm{mg} / \mathrm{kg}$ of extract, $D-100$ diabetic rats: animals received $100 \mathrm{mg} / \mathrm{kg}$ of extract 
Table 6 Effect of C. albidum extract on plasma lipid profile of diabetic rats

\begin{tabular}{llllll}
\hline Treatment/group & Parameter & & & \\
\cline { 2 - 6 } & Total-C & HDL-C & TGL & VLDL-C & LDL-C \\
\hline Group A (NC) & $159.71 \pm 15.39^{\mathrm{a}}$ & $62.14 \pm 9.80^{\mathrm{a}}$ & $126.70 \pm 21.70^{\mathrm{a}}$ & $13.38 \pm 4.50^{\mathrm{a}}$ & $84.50 \pm 3.60^{\mathrm{a}}$ \\
Group B (DC) & $268.50 \pm 16.85^{\mathrm{b}}$ & $45.40 \pm 8.26^{\mathrm{b}}$ & $195.50 \pm 22.82^{\mathrm{b}}$ & $38.84 \pm 5.60^{\mathrm{b}}$ & $183.60 \pm 25.70^{\mathrm{b}}$ \\
Group C (ND-200) & $115.80 \pm 20.25^{\mathrm{c}}$ & $71.40 \pm 10.88^{\mathrm{c}}$ & $65.80 \pm 12.30^{\mathrm{c}}$ & $13.20 \pm 1.40^{\mathrm{a}}$ & $31.70 \pm 2.00^{\mathrm{c}}$ \\
Group D (ND-100) & $128.78 \pm 28.20^{\mathrm{d}}$ & $75.67 \pm 10.60^{\mathrm{c}}$ & $108.78 \pm 10.00^{\mathrm{d}}$ & $21.60 \pm 2.50^{\mathrm{c}}$ & $32.60 \pm 3.40^{\mathrm{c}}$ \\
Group E (D-200) & $187.58 \pm 19.20^{\mathrm{e}}$ & $60.00 \pm 8.60^{\mathrm{a}}$ & $140.50 \pm 12.70^{\mathrm{e}}$ & $28.60 \pm 3.50^{\mathrm{d}}$ & $98.70 \pm 13.00^{\mathrm{d}}$ \\
Group F (D-100) & $210.80 \pm 13.60^{\mathrm{f}}$ & $58.40 \pm 5.70^{\mathrm{a}}$ & $154.42 \pm 24.00^{\mathrm{f}}$ & $30.60 \pm 3.00^{\mathrm{d}}$ & $121.60 \pm 20.40^{\mathrm{f}}$ \\
\hline
\end{tabular}

The results are presented as mean \pm SEM. Value not sharing a common superscript on the same column differ significantly $(p<0.05)$ from each other

The lipid concentrations are expressed in mg/DI. NC normal control rats: animals received distilled water in place of extract, DC diabetic control rats: animals received distilled water in place of extract, $N D-200$ non-diabetic rats: animals received $200 \mathrm{mg} / \mathrm{kg}$ body weight of extract, $N D-100$ non-diabetic rats: animals received $100 \mathrm{mg} / \mathrm{kg}$ body weight of extract, $D-200$ diabetic rats: animals received $200 \mathrm{mg} / \mathrm{kg}$ of extract, $D$ - 100 diabetic rats: animals received $100 \mathrm{mg} / \mathrm{kg}$ of extract

$(p<0.05)$ increased in diabetic control rats as compared to normal control. However, no significant change was observed in the level of this parameter in normal and diabetic rats treated with both doses of the extract relative to normal control. The levels of SOD, GSH, GR, GST and GPx were significantly decreased in diabetic rats relative to normal control. No significant change was observed in these parameters in normal rats treated with 100 and $200 \mathrm{mg}$ of extract per $\mathrm{kg}$ body weight. The levels of SOD, GSH, GR, GST and GPx were significantly increased at the dose of $200 \mathrm{mg} / \mathrm{kg}$ body weight in diabetic rats treated with the extract relative to diabetic controls. In diabetic rats treated with $200 \mathrm{mg}$ extract per $\mathrm{kg}$ bodyweight, these parameters were increased to a level not significantly different from normal control.

\section{Assessment of kidney antioxidant status}

The effect of C. albidum fruit-skin extract on the levels of LPO, SOD, GSH, GR, GST and GPx in the kidney of diabetic rats is shown in Table 8. The trend observed in the kidney was similar to that of the liver, as the effect of diabetes on these parameters was reversed with $200 \mathrm{mg} / \mathrm{kg}$ body weight dose of extract in diabetic rats treated with the extract. Thus, the study showed that the fruit-skin extract of C. albidum is beneficial as it reversed diabetes induced oxidative stress in the liver and kidney of rats.

\section{Discussion}

Diabetes mellitus is a metabolic disease associated with impaired glucose and lipid metabolism. (Mediani et al., 2018) The present study was designed to evaluate the effect of the ethanolic extract of C. albidum fruit-skin on STZ-diabetic albino rats.

Phytochemical investigations of the extract revealed abundant amounts of flavonoids and alkaloids with moderate and trace concentrations of tannins and saponins, respectively (Table 2). This finding is in agreement with the studies of Ibrahim et al. (2017) which demonstrated that the bioactive compounds in these secondary plant metabolites have antioxidant, anti-inflammatory, hypoglycaemic and hypolipidemic properties due to their bioactive compounds. Thus the presence of these phytochemicals in the fruit-skin of C. albidum is an indication that it might be beneficial in the management, prevention and treatment of

Table 7 Effect of C. albidum extract on levels of lipid peroxidation (LPO), superoxide dismutase (SOD), glutathione (GSH), glutathione reductase (GR), glutathione transferase (GST) and glutathione peroxidase (GPx) in the liver of diabetic rats

\begin{tabular}{|c|c|c|c|c|c|c|}
\hline \multirow[t]{2}{*}{ Treatment/group } & \multicolumn{6}{|l|}{ Parameter } \\
\hline & LPO & SOD & GSH & $G R$ & GST & GPx \\
\hline Group A (NC) & $38.2 \pm 4.32^{a}$ & $671.73 \pm 52.00^{a}$ & $6.10 \pm 0.53^{a}$ & $14.50 \pm 0.50^{a}$ & $36.80 \pm 4.50^{a}$ & $7.50 \pm 0.40^{a}$ \\
\hline Group B (DC) & $56.3 \pm 8.70^{b}$ & $450.70 \pm 50.25^{b}$ & $3.70 \pm 0.20^{b}$ & $6.80 \pm 0.50^{b}$ & $15.70 \pm 1.40^{b}$ & $3.40 \pm 0.30^{b}$ \\
\hline Group C (ND-200) & $37.2 \pm 5.45^{\mathrm{a}}$ & $685.60 \pm 4.80^{\mathrm{a}}$ & $6.30 \pm 0.50^{a}$ & $14.00 \pm 1.40^{a}$ & $35.00 \pm 5.50^{a}$ & $7.40 \pm 0.60^{a}$ \\
\hline Group D (ND-100) & $36.8 \pm 5.60^{a}$ & $682.50 \pm 6.00^{\mathrm{a}}$ & $5.90 \pm 0.80^{a}$ & $13.80 \pm 1.6^{\mathrm{a}}$ & $37.20 \pm 6.70^{a}$ & $7.88 \pm 0.70^{a}$ \\
\hline Group E (D-200) & $37.4 \pm 6.58^{a}$ & $686.46 \pm 2.73^{a}$ & $5.80 \pm 0.80^{a}$ & $13.05 \pm 2.50^{a}$ & $34.70 \pm 6.80^{a}$ & $7.20 \pm 0.70^{a}$ \\
\hline Group F (D-100) & $38.8 \pm 5.55^{\mathrm{a}}$ & $652.45 \pm 4.70^{c}$ & $5.60 \pm 0.60^{c}$ & $12.00 \pm 2.00^{c}$ & $30.80 \pm 0.40^{c}$ & $6.8 \pm 0.63^{c}$ \\
\hline
\end{tabular}

The results are presented as mean \pm SEM. Value not sharing a common superscript on the same column differ significantly $(p<0.05)$ from each other Units: LPO (nmole/g protein), SOD (units/g protein), GSH ( $\mu \mathrm{g} / \mathrm{mg}$ protein), GR ( $\mu$ moles of GSH utilized/min/mg protein), GST ( $\mu \mathrm{moles}$ of CDNB-GSH conjugate formed $/ \mathrm{min} / \mathrm{mg}$ protein), GPx ( $\mu \mathrm{g}$ of GSH consumed/min/mg protein). NC normal control rats: animals received distilled water in place of extract, DC diabetic control rats: animals received distilled water in place of extract, ND-200 non-diabetic rats: animals received $200 \mathrm{mg} / \mathrm{kg}$ body weight of extract. ND-100 nondiabetic rats: animals received $100 \mathrm{mg} / \mathrm{kg}$ body weight of extract, $D-200$ diabetic rats: animals received $200 \mathrm{mg} / \mathrm{kg}$ of extract, $D$ - 100 diabetic rats: animals received $100 \mathrm{mg} / \mathrm{kg}$ of extract 
Table 8 Effect of C. albidum extract on levels of lipid peroxidation (LPO), superoxide dismutase (SOD), glutathione (GSH), glutathione reductase (GR), glutathione transferase (GST) and glutathione peroxidase (GPX) in the kidney of diabetic rats

\begin{tabular}{|c|c|c|c|c|c|c|}
\hline \multirow[t]{2}{*}{ Treatment/group } & \multicolumn{6}{|l|}{ Parameter } \\
\hline & $\overline{\mathrm{LPO}}$ & SOD & GSH & GR & GST & GPx \\
\hline Group A (NC) & $1.68 \pm 0.16^{a}$ & $66.00 \pm 5.00^{\mathrm{a}}$ & $5.60 \pm 0.50^{a}$ & $15.50 \pm 0.50^{\mathrm{a}}$ & $26.80 \pm 3.50^{\mathrm{a}}$ & $4.50 \pm 0.40^{a}$ \\
\hline Group B (DC) & $2.62 \pm 0.10^{b}$ & $40.50 \pm 5.25^{b}$ & $2.60 \pm 0.20^{b}$ & $7.80 \pm 0.5^{b}$ & $15.70 \pm 0.40^{b}$ & $2.50 \pm 0.30^{b}$ \\
\hline Group C (ND-200) & $1.65 \pm 0.25^{a}$ & $68.60 \pm 4.00^{\mathrm{a}}$ & $5.40 \pm 0.50^{\mathrm{a}}$ & $14.20 \pm 1.40^{\mathrm{a}}$ & $24.70 \pm 5.30^{\mathrm{a}}$ & $4.66 \pm 0.67^{a}$ \\
\hline Group D (ND-100) & $1.73 \pm 0.15^{\mathrm{a}}$ & $65.80 \pm 5.00^{\mathrm{a}}$ & $5.45 \pm 0.60^{a}$ & $14.80 \pm 0.60^{\mathrm{a}}$ & $25.10 \pm 4.70^{\mathrm{a}}$ & $4.58 \pm 0.40^{a}$ \\
\hline Group E (D-200) & $1.76 \pm 0.43^{\mathrm{a}}$ & $63.46 \pm 1.62^{\mathrm{a}}$ & $5.80 \pm 0.66^{\mathrm{a}}$ & $13.70 \pm 1.50^{\mathrm{a}}$ & $27.30 \pm 5.20^{a}$ & $4.42 \pm 0.74^{a}$ \\
\hline Group F (D-100) & $1.62 \pm 0.18^{\mathrm{a}}$ & $70.20 \pm 2.00^{\mathrm{a}}$ & $5.70 \pm 0.80^{\mathrm{a}}$ & $13.00 \pm 2.40^{c}$ & $22.50 \pm 1.50^{c}$ & $4.38 \pm 0.65^{a}$ \\
\hline
\end{tabular}

The results are presented as mean \pm SEM. Value not sharing a common superscript on the same column differ significantly $(p<0.05)$ from each other Units: LPO (nmole/g protein), SOD (units/g protein), GSH ( $\mu \mathrm{g} / \mathrm{mg}$ protein), GR ( $\mu$ moles of GSH utilized/min/mg protein), GST ( $\mu$ moles of CDNB-GSH conjugate formed $/ \mathrm{min} / \mathrm{mg}$ protein), GPx ( $\mu \mathrm{g}$ of GSH consumed $/ \mathrm{min} / \mathrm{mg}$ protein). $N C$ normal control rats: animals received distilled water in place of extract, $D C$ diabetic control rats: animals received distilled water in place of extract, ND-200 non-diabetic rats: animals received $200 \mathrm{mg} / \mathrm{kg}$ body weight of extract. ND-100 nondiabetic rats: animals received $100 \mathrm{mg} / \mathrm{kg}$ body weight of extract, $D-200$ diabetic rats: animals received $200 \mathrm{mg} / \mathrm{kg}$ of extract, $D$ - 100 diabetic rats: animals received $100 \mathrm{mg} / \mathrm{kg}$ of extract

a wide range of diseases which underscores its use by traditional medicine practitioners in Nigeria.

The results from this study also revealed a drastic loss of weight of untreated diabetic rats compared to nondiabetic animals (Table 3). Similar loss in weight has been observed in STZ-diabetic rats by Mestry, Dhodi, Kumbhar, and Juvekar (2017) and this was attributed to the loss in muscle and adipose tissue resulting from excessive breakdown of tissue protein and fatty acids occasioned by the observed decrease in plasma insulin concentration. In diabetic individuals, the lack of insulin causes inhibition of protein synthesis and increased degradation which increases amino acid levels in the blood to be subsequently used for gluconeogenesis (Qian et al., 2015). The dose-dependent improvement in body weight and plasma insulin levels (Table 4) observed in diabetic rats treated with the extract is a likely indication that the extract is beneficial in preventing muscle wasting and protein turn over.

The results obtained for plasma glucose of STZdiabetic rats showed high level of glucose as compared to the normal non-diabetic rats (Table 4). This result is in accordance with the findings of several authors using STZ-diabetic rats (Dotzert, McDonald, Murray, Noble, \& Melling, 2017). Deshmukh and Jain (2015) report shows that hyperglycaemia could arise from either a defect in insulin secretion as in the case of insulindependent diabetes mellitus (type I) or a defect in insulin resistance (receptor or post receptor defect) as in the case of non-insulin-dependent diabetes mellitus (type 2) (Deshmukh \& Jain, 2015). Thus the increased plasma glucose concentration and the corresponding decreased plasma insulin concentration of the diabetic control rats (Table 4) is an indication of insulin-dependent diabetes (type 1). The significantly decreased plasma glucose concentration of non-diabetic rats (Table 4) treated with $200 \mathrm{mg}$ of the extract per $\mathrm{kg}$ bodyweight is a likely indication that the extract has anti-hyperglycaemic properties. Thus the significantly decreased plasma glucose level in diabetic rats treated with same dose of the extract (Table 4) relative to diabetic control rats is a confirmation of its anti-hyperglycaemic or anti-diabetic properties. The secondary metabolites present in the extract might be responsible for the antidiabetic action. Due to the rich flavonoid and alkaloid contents in the fruit skin of C. albidum, these components may be the main antidiabetic principles of the extract. Emerging experimental evidence indicate that flavonoids and alkaloids possess potential antioxidative properties that may protect pancreatic islets and help in regeneration of $\beta$ cells which in turn may lead to increase in insulin levels as observed in the present study (Table 4). In addition, flavonoids and alkaloids exert their effect either by promoting the entry of glucose into cells, thus stimulating glycolytic enzymes or by inhibiting the glucose-6-phosphatase in the liver, consequently reducing the release of glucose in blood (Tang, Chen, Xin, \& Alsa, 2017).

The level of plasma creatinine in the experimental rats was assessed in the present study. The increased level of plasma creatinine in diabetic control rats (Table 4) implies impaired renal function in the diabetic animals. Prior report by Amartey, Nsiah, and Mensah (2015) showed that alteration in serum creatinine concentration is one of the basic markers for kidney dysfunction. Treatment with extract at both doses produced significant decrease in the level of plasma creatinine of diabetic rats (Table 4). This finding is a likely indication that the extract may be beneficial in diabetic nephrology. However, further studies are required to proof the efficacy of the extract in this regard.

Plasma and tissue aminotransferases (ALT and AST) were also monitored in both treated and untreated diabetic and non-diabetic rats. Tissue damage is usually associated with the release of enzymes specific to the 
affected tissue or organ which could result in the increase in the activity of such enzymes in the blood (Aliyu, Adebayo, Gatsing, \& Garba, 2006). ALT is a cytoplasmic enzyme found in high amounts in the liver and an increase in ALT in the blood indicates liver damage, while AST is less specific than ALT as an indicator of liver damage (Parmar, Singh, Gupta, Pathak, \& Nayak, 2016). Thus the lack of significant change observed in the activity of ALT and AST in the plasma (Table 4) and tissues (Table 5) of normal rats administered C. albidum extract is a likely indication that the extract is not hepatotoxic. The significant increase in aminotransferases in the liver (Table 5) and the corresponding increase in the plasma (Table 4) observed in diabetic rats is an indication of increased de novo synthesis of the enzymes occasioned by the need for alternative source of energy through gluconeogenesis which could lead to increased catabolism of amino acids in the liver. ALT and AST reactions are extremely important for synthesis and degradation of amino acids. Increased activity of aminotransferases in the liver of diabetic rats has previously been reported by Rajesh and Sreenivas (2011).

The reversal of the effect of diabetes on the activity of the aminotransferases (ALT in particular) in the plasma (Table 4) and liver (Table 5) of diabetic rats at a dose of $200 \mathrm{mg} / \mathrm{kg}$ body weight of C. albidum fruit-skin extract is an indication of the hepatoprotective effect of the extract. A point worth noting is the lack of a significant change in kidney ALT and AST activities (Table 5) in rats in all the experimental groups. This is not unexpected as these enzymes are not markers of kidney function (Limdi \& Hyde, 2003). Again, the beneficial effect of the extract in providing protection against diabetesinduced liver and kidney dysfunction may be linked to the high flavonoid content of the extract. Several mechanisms can be deduced from the findings of other workers by which the flavonoid-enriched $C$. albidum fruit-skin extract reversed the effect of diabetes on the liver and kidney.

Lipid profile which is altered in diabetic state is one of the significant factors in development of cardiovascular disease (Einarson et al., 2018). The higher lipid (Total-C, TRG, VLDL-C and LDL-C) level seen in plasma of diabetic rats (Table 6) in the present study is in agreement with previous studies (Ganjali et al., 2017). The abnormal high concentration of serum lipids in diabetes is mainly due to the increase in the mobilization of free fatty acids from the peripheral depots, since insulin inhibits the hormone sensitive lipase (Tomkin \& Owens, 2017). On the other hand, glucagon, catecholamines and other hormones enhance lipolysis (Muller, Finan, Clemmensen, Marchi, \& Tschöp, 2017). The marked hyperlipidaemia observed in the diabetic rats may therefore be regarded as a consequence of the irregulated actions of lipolytic hormones on fats depots. The trend observed in the plasma lipid profile in the diabetic control rats was not entirely consistent as the plasma HDL-C was significantly lowered relative to control (Table 6). This finding is not unexpected as a low HDL-C has been reported to occur in blood of diabetes patients (Ganjali et al., 2017). The lowering of the plasma total-C, TGL, VLDL-C and LDL-C concentrations in non-diabetic and diabetic rats treated with the extract is an indication of a hypolipidemic effect. The significant increase in plasma HDL-C in non-diabetic rats treated with the extract is noteworthy as it benefited diabetic rats treated with the extract as the parameter was also significantly increased relative to diabetic control rats (Table 6). It is hypothesised that a high HDL-C may protect against cardiovascular disease and low HDL-C increases the risk for heart disease (Ganjali et al., 2017). Flavonoids are reported to be the major constituents of plant extracts that are shown to decrease blood lipid levels (Pires et al., 2018). Experimental evidence also indicates that flavonoids are possible inhibitors of 3-methylglutaryl-CoA (HMGCoA) reductase which participates in de novo cholesterol biosynthesis (Leopoldini, Malaj, Toscano, Sindona, \& Russo, 2010). The normalization of the insulin level in the extract-treated diabetic rats may also account for the observed reduction in plasma lipids as this hormone inhibits the activities of lipases (Ganjali et al., 2017).

Increased oxidative stress is one of the major causes of diabetes in experimental animals (Liguori et al., 2018) and it is linked to autooxidation of glucose, protein glycation, lipid peroxidation, dyslipidemia and lowered activities of enzymic and non-enzymic antioxidants (Lapena et al., 2018). The present results is consistent with these findings as it showed that the liver and kidney of diabetic rats had increased level of lipid peroxidation, decreased GSH concentration, altered lipid profile and decreased activities of antioxidant enzymes such as GPx, GR, GST and SOD (Tables 7 and 8). The increase in oxidative stress in liver and kidney of diabetic rats may account for the observed liver and kidney dysfunction (Tables 4 and 5) and the altered lipid profile (Table 6). The decreased levels of GSH in the liver and kidney of diabetic rats (Tables 7 and 8) are not surprising as this is occasioned by the decreased activity of GR in both organs. GSH is regenerated from GSSG by GR (Gul, Kutay, Temocin, \& Hanninen, 2000). Thus a decreased activity of GR in the liver and kidney of diabetic rats would translate to a decreased level of GSH.

Administration of $200 \mathrm{mg} / \mathrm{kg}$ body weight dose of $C$. albidum fruit-skin extract alleviated the observed oxidative stress in both organs of diabetic rats by decreasing the level of lipid peroxidation and increasing the level of GSH and the activities of antioxidant enzymes such GPx, GR, GST and SOD (Tables 7 and 8). Thus the 
reversal of oxidative stress by the extract is an indication that the extract has antioxidant properties and this is one of the mechanism by which the extract alleviate the toxic effect of diabetes in the liver and kidney. The antioxidant effect of C. albidum is due to the presence of flavonoids which are known for their chelating property and protection against free radical attacks (Nabavi, Nabavi, Alinezhad, Zare, \& Azimi, 2012) Several studies have also shown that certain flavonoids can induce the activity and expression of enzymes associated with GSH biosynthesis and metabolism (Myhrstad, Carlsen, Nordstrom, Blomhoff, \& Moskaug, 2002). By inducing the expression of antioxidant defence enzymes, these flavonoids have the potential to have long-lasting effects on cellular function. This, in turn, could be highly beneficial to cells exposed to chronic oxidative stress.

\section{Conclusions}

In conclusion, the findings of the present study indicate that administration of $200 \mathrm{mg} / \mathrm{kg}$ body weight dose of $C$. albidum fruit-skin extract has hypoglycaemic, hypolipidemic and antioxidant properties. The antioxidant properties occasioned by its abundant flavonoid and alkaloid contents may be responsible for the reversal of the effect of diabetes on some of the biochemical parameters in Wister rats. Further studies are recommended with the use of more animals and higher doses to ascertain the applicability of the plant extract in diabetic patients.

\section{Abbreviations}

CAT: Catalase; CDNB: 1-Chloro-2,4, dinitrobenzene; DM: Diabetes mellitus; DTNB: 5,5 Dithiobis (2-nitrobenzoic acid); GPx: Glutathione peroxidise; GR: Glutathione reductase; GSH: Glutathione; GST: Glutathione-s-transferase; HDL-C: High-density cholesterol; L-ALT: L-alanine aminotransferases; L-AST: Laspartate aminotransferase; LDL-C: Low-density lipoprotein-cholesterol; LPO: Lipid peroxidation; MDA: Malondialdehyde; SOD: Superoxide dismutase; STZ: Streptotozin; T2DM: Type 2 diabetes mellitus; TBARS: Thiobarbituric acid reactive substance; Total-C: Total cholesterol; TRG: Triglycerides; VLDL-C: Very low-density lipoprotein-cholesterol

\section{Acknowledgements}

The authors are grateful to the laboratory staff of the Department of Biochemistry, Delta State University, Abraka, Nigeria, for their assistance during the course of the biochemical analysis.

\section{Funding}

The authors declare that this work had no external funding.

\section{Availability of data and materials}

All data used for this study will be made available on request by the corresponding author.

\section{Authors' contributions}

HEK and TE carried out the experiments under the supervision of SOA. Al authors were involved in the experimental design and conceptual frame work. The write up was done by HEK and TE and SOA carried out the technical and language check. All authors have approved the submitted version of the work and have agreed to be personally accountable to the work.

\section{Ethics approval}

Treatment of the animals was in accordance with the principles of Laboratory animal care $(\mathrm{NIH}, 1985)$

Consent for publication

Not applicable.

\section{Competing interests}

The authors declare that they have no competing interests.

\section{Publisher's Note}

Springer Nature remains neutral with regard to jurisdictional claims in published maps and institutional affiliations.

\section{Author details}

'Department of Biochemistry, Delta State University, P.M.B 1, Abraka, Nigeria. 2Department of Medical Biochemistry, Delta State University, P.M.B 1, Abraka, Nigeria.

Received: 2 February 2019 Accepted: 12 June 2019

Published online: 21 June 2019

\section{References}

Adepoju, O. T., \& Adeniji, P. O. (2012). Nutrient composition and micronutrient potential of three wildly grown varieties of African star apple (Chrysophyllum albidum) from Nigeria. African Journal of Food Science, 6(12), 344-351.

Aliyu, R., Adebayo, A. H., Gatsing, D., \& Garba, I. H. (2006). The effects of ethanolic leaf extract of Commiphora Africana (Burseraceae) on rat liver and kidney functions. Journal of Pharmacology and Toxicology, 2, 373-379.

Alloubani, A., Saleh, A., \& Abdelhafiz, I. (2018). Hypertension and diabetes mellitus as predictive risk factors for stroke. Diabetes Metabolic Syndrome, 12(4), 577-584.

Amartey, N. A. A., Nsiah, K., \& Mensah, F. O. (2015). Plasma levels of uric acid, urea and creatinine in diabetes who visit the clinical analysis laboratory (Can-Lab) at Kwame Kkrumah University of Science and Technology, Kumasi, Ghana. Journal of Clinical Diagnosis Research, 9(2), BC05-BC09.

Asmat, U., Abad, K., \& Ismail, K. (2016). Diabetes mellitus and oxidative stress-A concise review. Saudi Pharmaceutical Journal, 34(5), 547-553.

Bada, S. O. (1997). Preliminary information on the ecology of Chrysophyllum albidum G. Don, in West and Central Africa. In O. A. Denton, A. O. Ladipo, M. A. Adetoro, \& M. B. Sarumi (Eds.), Proceedings of a national workshop on the potentials of the star apple in Nigeria, (NWPSAN' 97), (pp. 16-25). Ibadan: CENRAD.

Baum, J. A., \& Scandalios, J. G. (1981). Isolation and characterization of the cytosolic and mitochondrial superoxide dismutase of maize. Archives of Biochemistry and Biophysics, 206(2), 249-264.

Carlberg, I., \& Mannervik, B. (1985). Glutathione reductase. Methods in Enzymology, $113,484-490$.

Deshmukh, C. D., \& Jain, A. (2015). Diabetes mellitus: A review. International Journal of Pure and Applied Bioscience, 3(3), 224-230.

Dotzert, M. S., McDonald, M. W., Murray, M. R., Noble, E. G., \& Melling, C. W. J. (2017). Effect of combined exercise versus aerobic-only training on skeletal muscle lipid metabolism in a rodent model of type 1 diabetes. Canadian Journal of Diabetes, 42(4), 404-411.

Einarson, T. R., Acs, A., Ludwig, C., \& Panton, U. H. (2018). Prevalence of cardiovascular disease in type 2 diabetes: A systematic literature review of scientific evidence from across the world in 2007-2017. Cardiovascular Diabetology, 17(1), 83

Flohé, L., \& Günzler, W. A. (1984). Assay of glutathione peroxidase. Methods in Enzymology, 105, 115-121.

Ganjali, S., Dallinga-Thie, G. M., Simental-Mendía, L. E., Banach, M., Pirro, M., \& Sahebkar, A. (2017). HDL functionality in type 1 diabetes. Atherosclerosis, 267, 99-109.

Gul, M., Kutay, F. Z., Temocin, S., \& Hanninen, O. (2000). Cellular and clinical implications of glutathione. Indian Journal of Experimental Biology, 38, 625-634.

Gutteridge, J. M. C., \& Wilkins, C. (1982). Copper dependent hydroxyl radical damage to ascorbic acid. Formation of a thiobarbituric acid reactive products. FEBS Letter, 137, 327-340.

Habig, W. H., Pabst, M. J., \& Jakoby, W. B. (1974). Glutathione S-transferases. The first enzymatic step in mercapturic acid formation. Journal of Biological Chemistry, 249(22), 7130-7139. 
Harborne, J. B. (1998). Phytochemical methods - A guide to modern techniques of plant analysis. London: Chapman \& Hall.

Hunter, F. E., Gebicki, J. M., Hoffstein, P. E., Weinstein, J., \& Scott, A. (1963). Swelling and lysis of rat liver mitochondria induced by ferrous ion. Journal of Biological Chemistry, 238, 847-851.

Ibrahim, H. O., Osilesi, O., Adebawo, O. O., Onajobi, F. D., Karigidi, K. O., \& Muhammad (2017). Nutrients compositions and phytochemical contents of edible parts of Chrysophyllum albidum fruit. Journal of Nutrition and Food Science, 7, 579

Idowu, T. O., Iwalewa, E. O., Aderogba, M. A., Akinpelu, B. A., \& Ogundaini, A. O. (2006). Antinocicetive, anti-inflammatory and antioxidant activities of Eleagnine: An alkaloid isolated from seed cotyledon of C. albidum. Journal of Biological Chemistry, 6(6), 1029-1034.

Karalliedde, J., \& Gnudi, L. (2016). Diabetes mellitus, a complex and heterogenous disease, and the role of insulin resistance as a determinant of diabetic kidney disease. Nephrology, Dialysis Transplantation, 31, 206-213.

Keay, R. W. J. (1989). Trees of Nigeria, (p. 322). Oxford: Claendon Press.

Lapena, D., Ciofani, G., Calafiore, A. M., Cipollone, F., \& Porreca, E. (2018). Impaired glutathione related anti-oxidant defences in the arterial tissue of diabetic patients. Free Radical Biology and Medicine, 124, 525-531.

Leopoldini, M., Malaj, N., Toscano, M., Sindona, G., \& Russo, N. (2010). On the inhibitor effects of bergamot juice flavonoids binding to the 3methylglutaryl-CoA reductase (HMGR) enzyme. Journal of Agriculture and Food Chemistry, 58(19), 10768-10773.

Liguori, I., Russo, G., Curcio, F., Bulli, G., Aran, L., Della-Morte, D., ... Abete, P. (2018). Oxidative stress, aging, and diseases. Clinical Interventions in Aging, 13, 757-772. https://doi.org/10.2147/CIA.S158513.

Limdi, J. K., \& Hyde, G. M. (2003). Evaluation of abnormal liver function tests. Postgraduate Medical Journal, 79, 307-312.

Lowry, O. H., Rosebrough, N. J., Farr, A. L., \& Randall, R. J. (1951). Protein measurement with the Folin phenol reagent. Journal of Biological Chemistry, $193,265-275$

Lyons, T. J. (1992). Lypoprotein glycation and its metabolic complications. Diabetes, 41(2), 67-73.

Marshall, S. M. (2017). 60 years of metformin use: A glance at the past and a look to the future. Diabetologia, 60(9), 1561-1565.

Mediani, A., Abas, F., Maulidiani, M., Bakar Sajak, A. A., Khatib, A., Ping Tan, C., ... Lajis, N. H. (2018). Metabolomic analysis and biochemical changes in the urine and serum of streptozotocin-induced normal- and obese-diabetic rats. Journal of Physiology and Biochemistry. https://doi.org/10.1007/s13105-018-0631-3.

Mestry, S. N., Dhodi, J. B., Kumbhar, S. B., \& Juvekar, A. R. (2017). Attenuation of diabetic nephropathy in streptozotocin-induced diabetic rats by Punica granatum Linn. Leaves extract. Journal of Traditional and Complementary Medicine, 7(3), 273-280.

Misra, H. P., \& Fridovich, I. (1972). The role of superoxide ion in the auto-oxidation of epinephrine and a simple assay for superoxide dismutase. Journal of Biological Chemistry, 247, 3170-3175.

Muhammad, S. A., \& Abubakar, S. M. (2016). Qualitative and quantitative determination of phytochemicals in aqueous extract of Chrysophyllum albidum seed kernel. Bioscience and Biotechnology Research Asia, 13(2), 1201-1206.

Muller, T. D., Finan, B., Clemmensen, C. D., Marchi, R. D., \& Tschöp, M. H. (2017). The new biology and pharmacology of glucagon. Physiology Review, 97(2), 721-766.

Myhrstad, M. C. W., Carlsen, H., Nordstrom, O., Blomhoff, R., \& Moskaug, J. O. (2002). Flavonoids increase the intracellular glutathione level by transactivation of the g-glutamylcysteine synthetase catalytic subunit promoter. Free Radical Biology and Medicine, 32, 386-393.

Nabavi, S. M., Nabavi, S. F., Alinezhad, H., Zare, M., \& Azimi, R. (2012). Biological activities of flavonoid-rich fraction of Eryngium caucasicum trautv. European Review for Medical and Pharmacological Sciences, 3, 81-87.

Parmar, K. S., Singh, G. K., Gupta, G. P., Pathak, T., \& Nayak, S. (2016). Evaluation of De Ritis ratio in liver-associated diseases. International Journal of Medical Science and Public Health, 5(9), 1782-1788.

Pires, V. A., Cardozo-Junior, E. L., Ortmann, C. F., Maraschin, J. C., Favreto, W. A. J., Donaduzzi, C. M., ... Assreuy, J. (2018). Lipid lowering and antiatherogenic effects of Vitex megapotamica (Spreng) Moldenke in a mice experimental model. Journal of Ethnopharmacology, 215, 14-20.

Qian, K., Zhong, S., Xie, K., Yu, D., Yang, R., \& Gong, D. W. (2015). Hepatic ALT isoenzymes are elevated in gluconeogenic conditions including diabetes and suppressed by insulin at the protein level. Diabetes/Metabolism Research and Reviews, 31(6), 562-571.
Rajesh, M., \& Sreenivas, S. A. (2011). Ant-diabetic effects of aqueous ethanolic extract of Hibiscus rosasinensis $L$ on streptozotocin-induced diabetic rats and the possible morphologic changes in the liver and kidney. International Journal of Pharmacology, 7, 363-369.

Reitman, S., \& Frankel, S. (1957). A colorimetric method for the determination of serum glutamic-oxaloacetic and glutamic-pyruvate transaminases. American Journal of Clinical Pathololgy, 28, 56-63.

Sarfo, F. S., Mobula, L. M., Plange-Rhule, J., Ansong, D., \& Ofori-Adjei, D. (2018). Incident stroke among Ghanaians with hypertension and diabetes: A multicenter, prospective cohort study. Journal of the Neurological Sciences, $395,17-24$.

Sheweita, S. A., Mashaly, S., Newairy, A. A., Abdou, H. M., \& Eweda, S. M. (2016). Changes in oxidative stress and antioxidant enzyme activities in streptozotocininduced diabetis mellitus in rats: Role of Alhagi maurotum extracts. Oxidative Medicine and Cell Longevity. https://doi.org/10.1155/2016/5264064.

Tang, D., Chen, Q. B., Xin, X. L., \& Alsa, H. A. (2017). Anti-diabetic effect of three new norditerpenoid alkaloids in vitro and potential mechanisms via P13K/Akt signaling pathway. Biomedicine and Pharmacotherapy, 87, 145-152.

Tietz, F. (1969). Enzymic method for quantitative determination of nanogram amounts of total and oxidized glutathione: Application to mammalian blood and other tissues. Annals of Biochemistry, 27, 502-522.

Tomkin, G. H., \& Owens, D. (2017). Diabetes and dyslipidemia: Characterizing lipoprotein metabolism. Diabetes, Metabolic Syndrome and Obesity, 10, 333-343.

Wu, K. K., \& Huan, Y. (2008). Sreptozotocin-induced diabetes models in mice and rats. Current Protocols in Pharmacology, Chapter 5, 5.47.1-5.47.14.

Yandrapalli, S., Jolly, G., Horblitt, A., Sanaani, A., \& Aronow, W. S. (2017). Cardiovascular benefits and safety of non-insulin medications used in the treatment of type 2 diabetes mellitus. Postgradruate Medical Journal, 129(8), 811-821.

Zlatkis, A., Zak, B., \& Boyle, A. J. (1953). A new method for the direct determination of serum cholesterol. Journal of Laboratory and Clinical Medicine, 41, 486-492.

\section{Submit your manuscript to a SpringerOpen ${ }^{\circ}$ journal and benefit from:}

- Convenient online submission

- Rigorous peer review

- Open access: articles freely available online

- High visibility within the field

- Retaining the copyright to your article

Submit your next manuscript at $\boldsymbol{\nabla}$ springeropen.com 